Iken, A. 1972: Measurements of water pressure in moulins as part of a movement study of the White Glacier, Axel Heiberg Island, Northwest Territories, Canada. J. Glaciol. 11, 53-58.

Meier, M. F. 1973: Hydraulics and hydrology of glaciers. Publ. int. Ass. Hydrol. Scient. 107, 353-370.

Röthlisberger, H. \& Lang, H. 1987: Glacial hydrology. In Gurnell, A. M. \& Clark, M. J. (edit.) Glacio-fluvial sediment transfer, 207-284. London: Wiley.

Shreve, R. L. 1972: Movement of water in glaciers. J. Glaciol. 11, 205-214.

Thomsen, H. H. 1986: Photogrammetric and satellite mapping of the margin of the Inland Ice, West Greenland. Ann. Glaciol. 8, 164-167.
Thomsen, H. H. 1988: Mass balance, ice velocity and ice temperature at the Inland Ice margin north-east of Jakobshavn, central West Greenland. Rapp. Grønlands geol. Unders. 140.

Thorning, L. \& Hansen, E. 1987: Electromagnetic reflection Survey 1986 at the Inland Ice margin of the Pakitsoq basin, central West Greenland. Rapp. Grønlands geol. Unders. 135, 87-98.

Thorning, L., Thomsen, H. H. \& Hansen, E. 1986: Geophysical investigations at the Inland Ice margin of the Pâkitsoq basin, central West Greenland. Rapp. Gronlands geol. Unders. 130, 114-121.

\title{
Electromagnetic reflection survey 1987 in key areas of the Pâkitsoq basin at the margin of the Inland Ice, central West Greenland
}

\author{
Leif Thorning and Egon Hansen
}

The EMR surveys of previous years (Thorning et al., 1986; Thorning \& Hansen, 1987) provided the ice-thickness data necessary for a detailed evaluation of the glaciological-hydrological conditions of the Inland Ice required for planning a hydropower plant at Pâkitsoq (Thomsen et al., 1986). This evaluation also identified some locations where ambiguity in the hydrological interpretation resulted in uncertainties in the estimate of water supply to the Pâkitsoq basin, because the data available did not allow the model to predict the direction of drainage of meltwater. Therefore, further geophysical work was undertaken to provide more detailed information on the subglacial relief of these localities on the ice.

\section{Field work 1987}

In May 1987, the helicopter-borne electromagnetic reflection (EMR) survey was continued in the Pâkitsoq area. As in previous years a Bell 206 Jetranger helicopter (Glace, OY-HBF) was used. The antenna (a better version in more durable materials) was mounted between the floats, and a new video recorder (Sony VO-6800PS, U-matic format) was used for the recording of EMR data, navigational check marks and navigator comments. A Del Norte line-of-sight navigation system with four remote stations was used for accurate positioning. The remote stations were placed so as to provide optimal coverage in the area of interest and therefore not at the same positions as in 1986. Flight elevation was $10 \mathrm{~m}$ above the ice surface. Operations were carried out from Jakobshavn airport with two or three refuelling stops at the camp at Lake 187, Pâkitsoq, where fuel had been landed by a larger helicopter.

The objective of the measurements was to obtain data from two specific areas where problems in hydrological interpretation existed. Thus, from the outset it was intended to utilize the navigation system for feedback of inflight information to navigator and pilot to make it possible to place lines closely and accurately over the critical areas. For a number of reasons this failed in the field, and instead navigation was visual, based on the combined experience of pilot and navigator, and aimed at a concentration of measurements in the areas of special interest. The navigational data were thus only recorded for later processing and were not used in flight.

\section{Processing of data}

The navigational data were processed by Bo Madsen, GTO, and transferred to GGU as calculated positions in UTM coordinates correlated with time. Due to errors in the recording of the data in the field, the positioning is less accurate than in 1986. This prolonged the subsequent processing of EMR data because a number of extra checks and corrections have been necessary.

The EMR data were processed using the same meth- 
ods and computer programs as in 1986 (Thorning \& Hansen, 1987). By October 1987 all profiles were reproduced in hard copy, digitized and processed to migrated ice-thickness data. However, the data have not yet been gridded into maps, as it is the intention to compile a combined data base of EMR data from 1985-1987, and scrutinize this for internal consistency before producing improved maps of ice-thickness; subglacial relief and hydrological potential.

Acknowledgements. We thank Bo Madsen, GTO (cooperation in the field); Ove Karlquist, Greenlandair Charter pilot (flying under difficult conditions); $M$. Svane Jørgensen and Dorthe Nyland Sørensen, GGU, (data processing); Anders Clausen (construction of the new radar antenna). Part of the cost of GTO's navigation system was defrayed by Energiafdelingen, GTO.

\section{References}

Thomsen, H. H., Thorning, L. \& Braithwaite, R. 1986: Vurdering af de gletscher-hydrologiske forhold på Indlandsisen ved Paakitsup Akuliarusersua, Ilulissat/Jakobshavn. Arbejdsnotat. Geol. Surv. Greenland. 82 pp.

Thorning, L., Thomsen, H. H. \& Hansen, E. 1986: Geophysical investigations at the Inland Ice margin of the Pâkitsoq basin, central West Greenland. Rapp. Gronlands geol. Unders. 130, 114-121.

Thorning, L. \& Hansen, E. 1987: Electromagnetic reflection survey 1986 at the Inland Ice margin of the Pâkitsoq basin, central West Greenland. Rapp. Gronlands geol. Unders. 135, 87-95.

\title{
Construction and testing of a lightweight radar for ice-thickness determinations on glaciers in the Pâkitsoq area, central West Greenland
}

\author{
Leif Thorning and Egon Hansen
}

Although the helicopter-borne EMR surveys described in Thorning \& Hansen (1988) resulted in excellent results from most of the catchment area of interest for the hydropower plant planned for Jakobshavn, there are still some local areas, such as the glacier lobes and ice-falls; where no meaningful data could be obtained. In the autumn of 1986 it was decided to construct a monopulse ice radar for use in such areas.

\section{Construction}

The instrument was constructed at GGU using a subcontractor for the high voltage power supply. The principle of the ice radar and good advice on its construction is given in Hodge (1978), which we followed closely. The principle and main components are shown in fig. 1 .

The instrument consists of two separate parts: the transmitter and the receiver.

The transmitter contains a $750 \mathrm{~V}$ DC power supply and a circuit containing four transistors. These are brought to avalanche and pulse with a repetition rate of approximately $6 \mathrm{kHz}$ over a load of $400 \mathrm{ohm}$. The choice of output frequency is then made through the choice of antenna length.

The signal from the receiver antenna is fed into an oscilloscope. The signal on the oscilloscope shows the direct pulse through air (used for triggering the sweep) and the reflected pulse delayed in proportion to the distance travelled through ice (fig. 2). The two-way travel time is calculated as the delay time for the arrival of the reflected pulse read off the oscilloscope plus the travel time for the direct pulse through air. For documentation a photograph is taken of the oscilloscope screen and its setting using a camera with date/time backpanel.

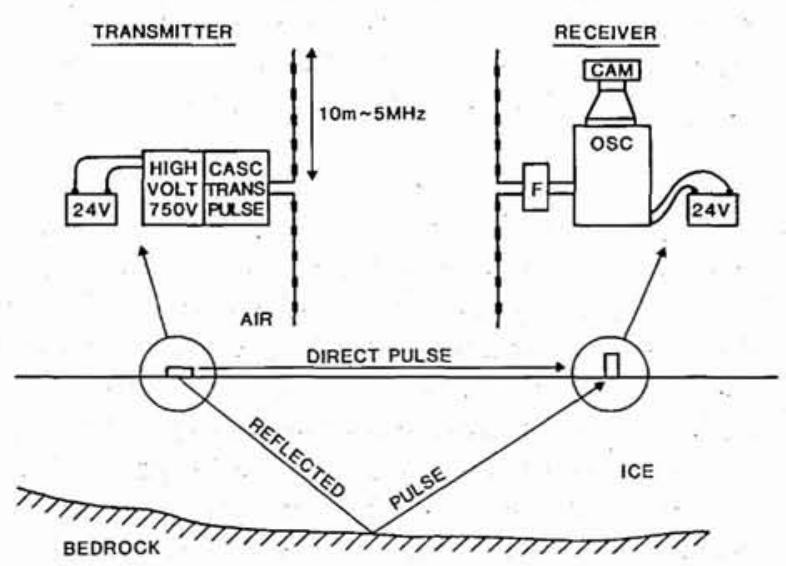

Fig. 1. Principle of the mono-pulse ice radar. For explanation, see text. 